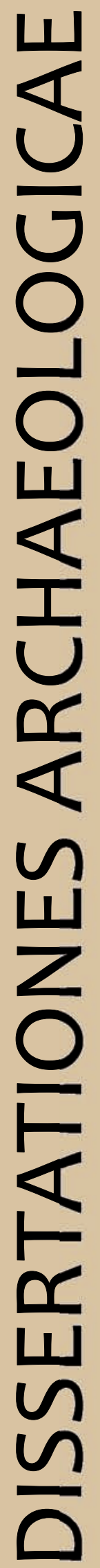

ex Instituto Archaeologico Universitatis de Rolando Eötvös nominatae

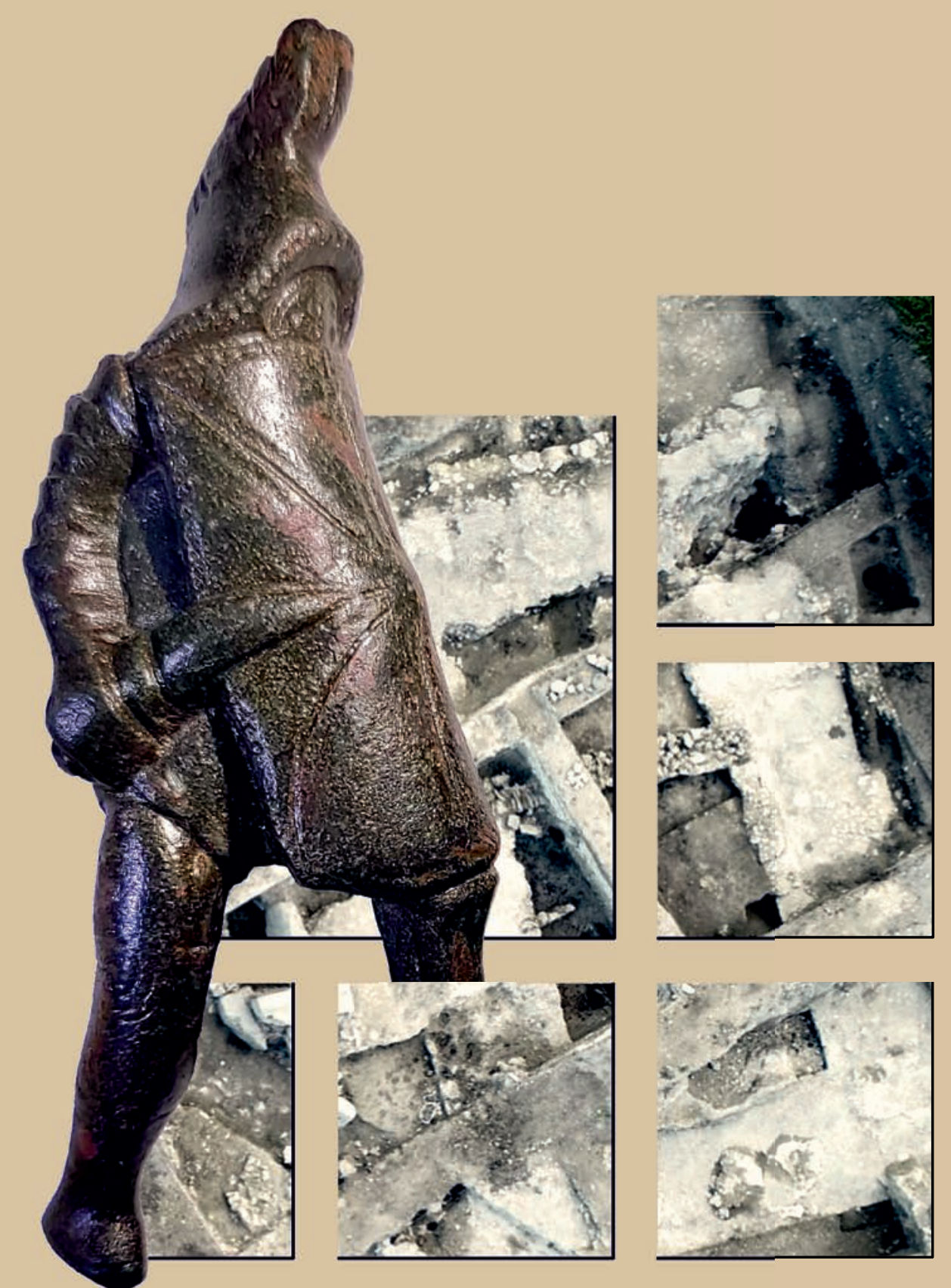

$$
\text { Ser. 3. No. 7. } 2019
$$




\section{Dissertationes Archaeologicae ex Instituto Archaeologico}

Universitatis de Rolando Eötvös nominatae Ser. 3. No. 7.

Budapest 2019 
Dissertationes Archaeologicae ex Instituto Archaeologico Universitatis de Rolando Eötvös nominatae

Ser. 3. No. 7.

Editor-in-chief:

DÁvid BARTUS

Editorial board:

LÁsZló BARTOSIEWICZ

LÁSZLÓ BORHY

ZOLTÁN CZAJLIK

IsTVÁN FELD

GÁBOR KALLA

PÁL RACZKY

MikLÓs SzABÓ

TivadAR VidA

Technical editor:

GÁBOR VÁCZI

Proofreading:

SZILVIA BARTUS-SZÖLLősI

ZsóFIA KondÉ

Aviable online at http://dissarch.elte.hu

Contact: dissarch@btk.elte.hu

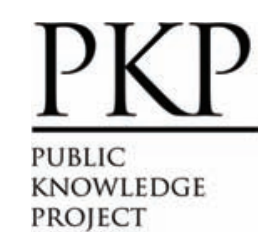

๑ ELTE Eötvös Loránd University, Institute of Archaeological Sciences

Layout and cover design: Gábor Váczi

Budapest 2019 


\section{CONTENTs}

\section{ARticles}

János Gábor TARBAY

The Casting Mould and the Wetland Find - New Data on the Late Bronze Age

Peschiera Daggers

Máté MeRvel

Late Bronze Age stamp-seals with negative impressions of seeds from Eastern Hungary

János Gábor TARBAY

Melted Swords and Broken Metal Vessels - A Late Bronze Age Assemblage

from Tatabánya-Bánhida and the Selection of Melted Bronzes

Ágnes ScHNEIDER

Multivariate Statistical Analysis of Archaeological Contexts: the case study

of the Early La Tène Cemetery of Szentlörinc, Hungary

Csilla SÁRÓ - Gábor LASSÁNYI

Bow-tie shaped fibulae from the cemetery of Budapest/Aquincum-Graphisoft Park

Dávid BARTus

Roman bronze gladiators - A new figurine of a murmillo from Brigetio

Kata DÉvAI

Re-Used Glass Fragments from Intercisa

Bence Simon

Rural Society, Agriculture and Settlement Territory in the Roman, Medieval and Modern Period Pilis Landscape

Rita RAKONCZAY

„Habaner“ Ofenkacheln auf der Burg Čabrad”

\section{FIELD REPORT}

Bence Simon - Anita Benes - Szilvia Joháczi - Ferenc BARnA

New excavation of the Roman Age settlement at Budapest dist. XVII, Péceli út (15127) site 


\section{Thesis Abstracts}

Kata SzILÁGYi

Die Silexproduktion im Kontext der Südosttransdanubischen Gruppe

der spätneolithischen Lengyel-Kultur

Norbert FARAGÓ

Complex, household-based analysis of the stone tools of Polgár-Csőszhalom

János Gábor TARBAY

Type Gyermely Hoards and Their Dating - A Supplemented Thesis Abstract

Zoltán Havas

The brick architecture of the governor's palace in Aquincum

Szabina Merva

'...circa Danubium...' from the Late Avar Age until the Early Árpádian Age-

$8^{\text {th }}-11^{\text {th }}$-Century Settlements in the Region of the Central Part of the Hungarian

Little Plain and the Danube Bend

Szabolcs Balázs NAGY

Noble Residences in the $15^{\text {th }}$ century Hungarian Kingdom - The Castles of Várpalota,

Ujlak and Kisnána in the Light of Architectural Prestige Representation

Ágnes KollátH

Tipology and Chronology of the early modern pottery in Buda 


\title{
Roman bronze gladiators \\ A new figurine of a murmillo from Brigetio
}

DÁvid BARTUS

Institute of Archaeological Sciences

ELTE Eötvös Loránd University

bartus.david@btk.elte.hu

\begin{abstract}
In summer 2019 a bronze figurine of a gladiator came to light during the excavations in the praetentura of the legionary fortress of Brigetio. This paper will briefly review all known bronze gladiator figurines from Brigetio, as well as the representations of gladiators in Roman art.
\end{abstract}

\section{Gladiators in Roman art}

\subsection{Introduction}

The representation of different kinds of gladiators is a frequent motif in most fields of Roman art. The institution of gladiatorial games (munera gladiatoria) was mentioned first in ancient sources in $264 \mathrm{BC}$ and became increasingly popular among Romans until the games were officially abolished in 404 AD by Emperor Honorius (Theodoretos, Hist. Eccl., V. 26.). This extreme popularity is reflected in the great number of survived representations and inscriptions concerning gladiators. ${ }^{1}$ Gravestones and graffiti (the latter mostly from Pompeii) are very important epigraphical documents mentioning the names, types and even the number of victories of the gladiators. Most of the representations come from the heyday of gladiatorial combat, the first three centuries of the Empire, when gladiators became common decorative elements on objects of everyday use.

The repertoire of representations and materials is wide and varied: mosaics and reliefs, brooches, ${ }^{2}$ lamps, pottery, glass vessels and knife-handles. ${ }^{3}$ The small figurines made of terracotta and bronze, and especially the bone and bronze knife-handles are very important sources on the weapons and armour of gladiators, since the number of survived equipment which can be securely connected with gladiators are very scarce. ${ }^{4}$ Among bronze figurines, all the popular gladiator types, the murmillo, the thraex, the secutor and the retiarius, and also the pair of a secutor and a retiarius are widely represented. ${ }^{5}$

1 On gladiators and the munera gladiatoria in general see LANDES - CAZES 1987; KöHNE - EwIGLEBEN 2000; JUNKELMANN 2000.

2 ProhászKa 2001.

3 On Roman bone and bronze knife-handles representing gladiators see MERCKLIN 1940; KOLENDO 1998; GotTschalk 2006; Bartus 2010.

4 Most of the survived weapons and equipment of gladiators came from one find from Pompeii (15 helmets, 17 greaves, 3 shoulder-plates, a shield and numerous fragments), however, the practicability of them is at least questionable, see KöHNE - EwigLEBEN 2000, 38-45.

5 Some less frequent or unidentifiable types of gladiators also appear among bronze figurines: BARTUS 2010, No. 14 [=Mercklin 1940, Anm. 63.] (hoplomachus); LANDES - CAZES 1987, 168-169, No. 86 (cruppellarius?); BABELon - Blanchet 1895, 420, No. 950-952 (unidentifiable); ReInACH 1897-1924, IV.112.9 (unidentifiable); 


\subsection{Murmillo}

The murmillo belongs to the group of heavy-armored gladiators. Its dress consisted of a loincloth (subligaculum) and a belt (balteus). The right arm was protected by an armguard made of leather or folded drapery (manica) and the left leg was protected by a bronze greave (ocrea). He held a large, rectangular shield (scutum) and a short sword (gladius). The most unique part of the murmillo's armour is the helmet, the only piece which differs from the otherwise identical armour of the secutor. The crest of the murmillo's helmet resembles a fish, which

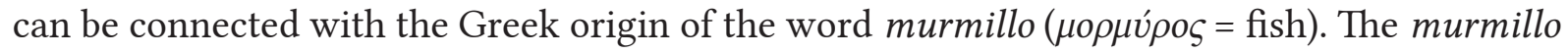
was often called Samnis in the earlier research, based on the assumption that the Samnis was the predecessor of the murmillo, however, according to Festus, the murmillo was earlier called Gallus: the famous sentence of the retiarius fighting the murmillo was "Non te peto, piscem peto - quid me fugis, Galle?" (Festus, De verb., 285). ${ }^{6}$ The duel between the murmillo and retiarius in the arena was the symbolic fight of the fish and the fisherman, ${ }^{7}$ however, the most frequent pairing in the first two centuries of the Roman Empire was the fight of the murmillo and the thraex.

There is a special group among the representations of murmillones (and also of thraeces), the bone knife-handles with inscribed shield. The first example of the group came from Ampurias, with the inscription "PARDVS" on the shield. ${ }^{8}$ The name "Pardus" appears frequently in the epigraphical material, even in the form of the name of a gladiator. ${ }^{9}$ The elaboration of the knife-handle itself is mediocre, but the typical features of the murmillo, the helmet, the large, rectangular shield with umbo, the manica, ocrea and the short gladius are well-recognisable. The closest analogy of the Ampurias knife-handle came from the northern cemetery of Savaria (Szombathely, Hungary) in 2006. A pair of bone knife-handles was found in a cinerary urn together with a coin of Anoninus Pius. One of them represents a murmillo, the other one is a thraex, with the inscriptions "PARDV(s)" and "SENILI(s)"10 on their shields, respectively. ${ }^{11}$ This unique set of knife-handles represents the most popular pair of gladiatorial combat and indicates that all knife-handles with the inscriptions "Pardus" and "Senilis"

etc. For a short summary of bronze gladiator representations see LANDES - CAZES 1987, 77-81.

6 The word murmillo is not frequent in ancient sources, see e. g. Suet., Cal., 32; 55; Suet., Nero 30; 47; Suet. Dom., 10; Iuven., Sat., 6,81; 8, 199-200; Plin., Nat. Hist., 7,55,7; Sen., Dialogi 1,4,4; Val. Max., 1,7,8; Cic., Phil., 3,31; 5,20; 6,10; 6,13; 7,17; 12,20; Florus, Epit., 2,8,38; Quintilianus, Inst. Orat., 6,3,61. There are more examples of the murmillones in the epigraphical material: AE 1908, 222; AE 1960, 139-140; AE 1971, 263; AE 1988, 25-26; CIL II2 353, 355-356, 359, 363, 365; CIL IV 2387, 2508, 4327, 4329, 4336, 4407, 7360, 9018; CIL V 1907; CIL VI 631, 10169, 10176, 10179-10180; CIL IX 465-466; CIL XII 3325-3326, 3330, 5836-5837; CIL XIII 1200; ESPÉRANDIEU 1929, 434, 436.

7 See the inscriptions with the expression "murmillo contrarete" (CIL II2 361, 363; CIL VI 10180; CIL II, 7, 363; ESPÉRANDIEU 1929, 436).

8 AE 1952, 110; Almagro 1952, 137; Bartus 2010, No. 1. In the first detailed publication of the object it was described erroneously as a mirror handle representing a "samnis" (PIERnAVIEJA Rozitis 1971-72, 382).

9 CIL VI 631 (Rome): “...pardus prov(ocator) vet(eranus)...”; CIL VI 33983.

10 The name "Senilis" appears frequently in the epigraphical material, but none of these can be connected with gladiators: AE 1904, 182; AE 1920, 69; AE 1962, 383; AE 1964, 6ad; AE 1971, 257; AE 1972, 446-447; AE 1975, 565; AE 1976, 422; AE 1995, 894, AE 2001, 2155; CIL II 4970,467c-e; 4970,468; CIL III 998, 1009, 1204, 1970, 4835, 5121, 5188, 5196a, 5439, 5499, 5504, 5907; CIL V 1052, 1267, 8224; CIL VI 2375, 2543, 21011, 31152, 32640; CIL X 8059,363-364; CIL XII 1922, 2752, 3890, 3926, 4152, 4212-4213, 5378; CIL XIII 823, 1090, 1888, 1984, 2770, 4028, 4207, 5567, 5930, 6347, 6638, 7499, 7537, 8237, 11771; SPEIDEL 1994, 96; HEp I 971; ILASant 1005,78; EsPÉRANDIEU 1929, 540; ILJug III 2568fo; ILLPRON 1457, 1962; LE BoHEC 2003, 315; RIB I, 1068, 1665 , $1755,2025$.

11 Bartus 2010, No. 32-33. 
were originally used in pairs, presumably in the second half of the second century AD. The two objects from Savaria are very similar to each other, with a lot of identical details created by routine-work, which means that the two knife-handles were most probably produced in the same workshop. Pardus and Senilis could be either famous gladiators of their age ${ }^{12}$ probably the second century $\mathrm{AD}$, or only the personifications of the popular pair of the murmillo and thraex.

The representations of murmillones are also very popular among Roman bronze figurines, ${ }^{13}$ and three of the four known bronze gladiators from Brigetio belong to this category.

\subsection{Thraex}

The thraex, similar to the murmillo, was also a heavy-armored gladiator. Apart form the manica and the subligaculum, he wore two long greaves (ocrea), because his small, almost square shield (parmula) did not provide sufficient protection for the legs. The helmet of the thraex (galea) was similar to that of the murmillo, but it was decorated with a griffin's head. His only weapon was the sica, a short sword with a curved blade which made easier to stab behind the enemy's shield. The sica is a well-recognizable weapon of the thraeces for it was always clearly elaborated on the representations and makes possible to distinguish the thraex (together with the smaller shield) from the otherwise nearly identical murmillo. ${ }^{14}$ The most frequent opponent of the thraex was the murmillo, which symbolized the fight of a barbarian soldier and a Roman legionnaire, however, as told by Suetionus, some Roman Emperors had great sympathy with thraex gladiators. ${ }^{15}$ Among bronze figurines, the representations of thraeces were as numerous as of the murmillones. ${ }^{16}$

12 Both Pardus and Senilis are "speaking names", Senilis could be the nickname of an elder gladiator with multiple victories. The assumption of J. Storch (SтоRсн 1986, 223), that the inscription "SENILI" is the genitivus of Senilus, the owner of the knife-handle, is not sustainable in view of the other object with the same inscription (see BARTUS 2010).

13 Fleischer 1967, 146-147, Nr. 196-197, Taf. 106 [=Reinach 1897-1924, IV.112.6-7. = Humer - Kremer 2011, 314, Nr. 479 (erroneously as secutor)]; Gschwantler 1986, 126, Kat. 186. Abb. 251 (erroneously as secutor); BABElon - Blanchet 1895, 417, No. 943 [=ReInach 1897-1924, II.194.7]; 417-418, No. 944 [=ReinaCH 1897-1924, II.194.6]; 418, No. 946; 419, No. 948; Garcia Serrano 1990, 180, No. 33; Durham 2012, No. 171; Katintcharov 1984, No. 214 [=Kunze 1990, 86, Abb. 38. = Reinach 1897-1924, III.156.10]; No. 215 [=KunZE 1990, 87-88, Abb. 39-40]; Froehner 1885, 57, No. 264 [=Reinach 1897-1924, II.194.3]; Bayard - Massy 1983, 92, Fig. 34; Marazov et al. 2005, 148, No. 147 (murmillo?); Von SAcken 1871, 113-114, Taf. XVIII.8; REINACH 1897-1924, II.194.1,4,8; III.155.7-9; III.156.1,3,8; IV.112.1,5,9(?); HARRIS 1994, No. 149; VermeUle Сomstock 1988, 98, No. 129; Eisenberg 2004, No. 85; Eisenberg 2014, No. 47 (erroneously as thraex).

14 The curve of the sica was often represented nearly as a right angle (Bartus 2010, No. 7 (Carnuntum); No. 14. (Italica); No. 32 (Savaria); No. 41 (Paris, Louvre); No. 43-44 (Paris, Bibliothèque Nationale)), however, in some cases the natural curviness of three-dimensional figurines can be misleading, as it was in the case of a bone knife-handle from Nîmes, interpreted as a thraex (BARTUs 2010, No. 24). The most obvious difference of the elaboration of the gladius and the sica can be seen on the pair of murmillo and thraex from Savaria (KISS 2006, 96; BARTus 2010, No. 32-33).

15 Caligula promoted thraex gladiators to officers of his Germanic bodyguards, but reduced the armour of murmillones: "Thraeces quosdam Germanis corporis custodibus praeposuit, murmillonum armaturas recidit."(Suet., Cal., 55). Titus was also supported the thraeces: "Quin et studium armaturae Thraecum prae se ferens saepe cum populo et voce et gestu ut fautor cavillatus est, verum maiestate salua nec minus aequitate."(Suet., Titus 8.). Domitian caused a man who scolded a thraex to be thrown into the arena to dogs: "Patrem familias, quod Thraecem murmilloni parem, munerario imparem dixerat, detractum spectaculis in harenam canibus obiecit cum hoc titulo: ,impie locutus parmularius." (Suet., Dom. 10). Apart from these, the word thraex - as a type of gladiator - is rare in ancient sources and epigraphical documents, see Cic., Phil., 6,13; Sen., Controversiae 3,10; Suet., Cal., 35; 54; CIL IV 2387, 2508; CIL VI 631, 10193, 10194, 10195, 10196, 10197; CIL IX 465, 466.

16 Bartus 2010, No. 38 [=Mercklin 1940, Anm. 63]; No. 40, Pl. III.40 [=Walters 1899, 358, No. 2966, fig. 84 = Mercklin 1940, Anm. 62 = Reinach 1897-1924, III.155.1]; No. 43 [=LANDES - Cazes 1987, 165, No. 83]; 


\subsection{Secutor and retiarius}

The secutor was actually a variant of the murmillo equipped with a different helmet. It is a globular helmet with flat surface and a small crest, its most typical features are the two tiny openings for the eyes. The helmet gives a fish-like appearance to its wearer, the secutor, whose traditional opponent was the retiarius, the most lightly armored gladiator with net and trident, resembling a fisherman. ${ }^{17}$ From about the turn of the second and third centuries AD, the fight of the secutor ${ }^{18}$ and retiarius became the most popular form of gladiatorial combat, instead of the murmillo and thraex. It is also reflected in the number of bronze figurines representing secutores and retiarii. ${ }^{19}$

There is a special group among the representations of gladiators: some bronze and bone knife-handle depicts the final stage of the fight of a secutor and a retiarius. The most famous and beautiful example of that is an ivory knife-handle from Aventicum. ${ }^{20}$ It represents the two gladiators clinging to each other at the end of the combat, the retiarius has already lost all of his weapons, trying to push off the sword of the secutor with one hand, and grasping the crest of its helmet with the other hand. But the outcome of the fight is not necessarily the victory of the secutor, rather a draw, the so-called "stantes missi". ${ }^{21}$ A very similar bone knife-handle was found in 2008 in Caerwent, ${ }^{22}$ and three bronze knife-handles from France also depict exactly the same fighting scene: one from Épône, one from Moselle, and another one with unknown provenance, from the department of Loir-et-Cher. ${ }^{23}$ The bronze pieces are generally less detailed and of lower quality than the bone and ivory ones, however, the example from

LANDEs - CAzes 1987, 168, No. 85, 173-174, No. 92 [=Esperandieu - Rolland 1959, 53, No. 96, pl. XXXIII]; 175-176, No. 94 [=BABElon - BlAnchet 1895, 418, No. 945 (erroneously as murmillo)]; 176-177, No. 95 [=BABELON - BlAnCHet 1895, 418-419, No. 947 (erroneously as murmillo)]; 177, No. 96; KöHNE - EwigleBEN 2000, 51, No. 42; 55, No. 49; Friedrichs 1871, 484, Nr. 2230 (thraex?); Kaufmann-Heinimann 1977, 83, Nr. 85, Taf. 89; VeličKović 1972, 171-172, No. 102; Menzel 1964, 25, Nr. 41, Taf. 18; Reinach 1897-1924, II.194.2; WALters 1899, 260, No. 1602 (with octagonal shield, probably fake), No. 1604; ReINACH 1889, 205, no. 188; Vermeule - CoMstock 1988, No. 96, No. 122; etc.

17 The other less common name of the secutor was the contraretiarius, see the inscription on a gravestone from Rome with the word (contra)ret(iarium): CIL VI 33983. The word secutor appears more frequently on inscriptions: AE1899, 53; AE 1989, 395; AE 1994, 1236; CIL III 8825, 8830; CIL V 563, 3459; CIL VI 10190; CIL X 7297;CIL XI 740; CIL XII 1596; CIL XIV 2949; HEp II 39. ILJug III 2267; and also in ancient sources: Suet., Cal., 30; SHA, Comm., 15,8; Iuv., Sat., 8,210.

18 Bartus 2010, No. 9, Pl. VI.9; No. 20, Pl. VI.20 [=Boucher et al. 1980, 75, No. 374 = Landes - Cazes 1987, 166-168, No. 84]; No. 28, Pl. VI.28; No. 32, Pl. VI.32; No. 39 [=Mercklin 1940, Anm. 62]; No. 41, Pl. VI.41 [=Babelon - Blanchet 1895, 419, No. 949]; Landes - Cazes 1987, 169-170, No. 87 [=OggianoBitar 1984, 116, No. 249]; 170-171, No. 88 [=Leibundgut 1976, 56-57, Nr. 36, Taf. 42 = Reinach 1897-1924, III.156.4]; 171-172, No. 89, 172-173, No. 90, 173, No. 91; Vujović 2011, 265, T.VII.2 [=DrČA 1991, 23-24, No. 13]; Boucher et al. 1980, 75, note 1; Reinach 1889, 205-206, 187,189; Franken 1994, 481-482, Nr. 89, Abb. 215-216 =REINACH 1897-1924, III.156.4]; etc.

19 KöHne - Ewigleben 2000, 59, No. 57; FAider-Feytmans 1979, 89, No. 91, Pl. 56; Babelon - Blanchet 1895 , 415, No. 941 (erroneously as bestiarius); 415-416, No. 942 [=LANDES - CAZES 1987, 174-175, No. 93.=REINACH 1897-1924, II.195.2]; Garcia Serrano 1990, 180, No. 34; VeličKović 1972, 170-171, No. 100 [=Vujović 2011, 263, T.VII.1]; Fleischer 1967, 147, Nr. 198, Taf. 106; ReInACH 1897-1924, IV.112.4,8; FrANKen 1994, 479-481, Nr. 88, Abb. 213-214; Faust 2005, 161-163, Nr. 7; etc.

20 Mayor 1904, 117-136; Mercklin 1940, Anm. 64; Degen 1984, 173, Abb. 6; Bron 1985, 33-34, Fig. 4-5. The knife handle was dated to the second half of the third century AD on stilistical ground by Ch. Bron.

21 In some cases, when two gladiators cannot beat each other after a long and skillful fight, both could leave the arena undefeated. See e. g. CIL XII 2747 (Cavillargues, Gallia Narbonensis); EAOR V, App. 4a-b (Vienne), App. 4c (Lyon).

22 Bartus - Grimm 2010, 321-324.

23 Mayor 1904, 133-134, fig. 47; Feugère 2004, 34-35. 
Moselle is relatively rich in detail, compared with the other two bronzes, which are of very low quality and show local influence, especially the face of the retiarius on the knife-handle from Loir-et-Cher. ${ }^{24}$ Although we lack any data on the production of the objects, differences in quality indicate that they were produced in separate workshops. The exceptions to this are the knives from Moselle and Loir-et-Cher which are very similar in almost every detail. They are probably from the same workshop, though not from the same mould. The similar composition of the fighting scene and the identical posture of the gladiators indicate that the five knife handles could have had a common prototype, which may have been inspired by a drawing in a so-called 'pattern-book', rather than by a sculpture.

\subsection{Other types of gladiators}

Some other types of gladiators (provocatores, hoplomachi, essedarii, etc.) were also represented in Roman art, but they are extremely rare among bronze figurines. ${ }^{25}$

\section{Bronze figurines from Brigetio in museum collections}

There are three bronze figurines of gladiators from Brigetio in the collection of the Hungarian National Museum, however, one of them is now lost. One of the surviving examples was found in 1927 during ploughing near the legionary fortress (Szőny-Bélapuszta). ${ }^{26}$ The well-elaborated figurine represents a gladiator standing on a flat, elliptical base stepping forward with his slightly bent left leg. The sword is missing from the right hand, the left arm is broken. Both legs are protected by greaves decorated with small incised grooves, the laces are represented by horizontal incised lines on the calves. The gladiator is wearing a subligaculum and a balteus, the upper body is naked except for the manica on the right arm and the typical helmet. The sword and the shield of the gladiator is missing, therefore the only way to distinguish between a thraex and a murmillo is observing the greaves. The gladiator wears greaves on both legs, which identifies him as a thraex. ${ }^{27}$

The two other figurines both represent murmillo gladiators. One of them was bought from Jenő Lengyel by the Hungarian National Museum in $1892 .{ }^{28}$ The gladiator is standing in a hide cylindrical base stepping forward with his slightly bent left leg protected by an ocrea. He is wearing a subligaculum and a balteus, the upper body is naked except for the manica on the right arm and the helmet. There is a sword in the right and a large rectangular shield in the left hand. The form of the base indicates that the figurine was a chariot mount.

The third figurine from Brigetio, now missing, also represents a murmillo. ${ }^{29}$ Based on the drawing published by I. Paulovics it stands on a circular base stepping forward with his slightly bent right leg protected by an ocrea. He is wearing a subligaculum and a balteus, the upper body is naked except for the manica on the left arm and the helmet. The gladiator is holding his right hand in front of his helmet, his left hand is behind his back. The shield is leaned

24 FEUGÈre 2004, fig. 9.

25 See in general Landes - Cazes 1987; Köhne - Ewigleben 2000; Junkelmann 2000.

26 Inv. no. 10.1927 .1 (formerly in the Kállay Collection), H: 117 mm. HómAn 1928, 109, T. XXIX (left); PAulovics 1942, 234-240, XXXV.t.1-2; FACsÁDy - Zsidi 2001, 117, No. 266.

27 I. Paulovics identified the gladiator erroneously as a „samnis” (PAulovics 1942, 236).

28 Inv. no. 16.1892.87, H: 132 mm. HAMPel 1912, 143; PAulovics 1942, 239, XXXV. t. 3.

29 Once in the Hungarian National Museum, no inventory number. PAUlovics 1942, 238-239, XXXV. t. 5. 
against his right knee, the sword lies on the ground. There are similar representations in the collection of the Bibliothèque Nationale ${ }^{30}$ and the British Museum, ${ }^{31}$ and one from Toulovo (Bulgaria). ${ }^{32}$ The only difference between the figurines that the object from Brigetio is a mirror image or the representation of a left-handed gladiator. ${ }^{33}$

\section{The new find from the legionary fortress of Brigetio}

In summer 2019 a bronze figurine of a gladiator (Fig. 1) came to light during the excavations in the praetentura of the legionary fortress of Brigetio. ${ }^{34}$ The exact findspot of the object is a trench parallel and next to the east side of the via praetoria, approximately 40 metres south of the porta praetoria. The trench was not part of the street, but a later (Late Roman or post-Roman) disturbance, probably during the removal of the stones of the sewer next to the via praetoria, which means that the figurine was in a secondary position without any usable stratigraphical or chronological information.

The bronze figurine ${ }^{35}$ represents a murmillo gladiator stepping forward with his slightly bent left leg protected by an ocrea. The left foot is missing. The ocrea is undecorated but the laces are represented by $\mathrm{V}$-shaped incised lines on the calf. There are some incised lines on the right foot as well. The gladiator is wearing a subligaculum and a balteus decorated with small incised dots, which is visible only on the back side of the object. The upper body is naked except for the manica on the right arm and the helmet. The crest of the helmet is decorated with very fine incised lines. There is a short sword in the right and a large rectangular shield in the left hand. The umbo of the shield is visible and the diagonals and median lines of the rectangle are marked with incised lines on the surface of the shield. The borders of the shield and the helmet are decorated with small hatches. The overall quality of the figurine is average.

As it was mentioned above, the find circumstances of the figurine do not help us to ascertain neither the function of the object nor its original place of use. Bronze figurines of gladiators, unlike similar knife handles, had no practical use, they were most probably personal objects, souvenirs from a munus gladiatorum. The owner of our bronze murmillo might be a soldier of the here stationed legio I adiutrix, who could buy the figurine in the nearby military amphitheatre west of the legionary fortress, sometime in the second or third century AD. ${ }^{36}$

\section{References}

Almagro, M. 1952: Las inscripciones ampuritanas griegas, ibéricas y latinas. Barcelona.

Babelon, E. - Blanchet, J. A. 1895: Catalogue des bronzes antiques de la Bibliothèque Nationale. Paris.

30 Babelon - Blanchet 1895, 417, No. 943 [=Reinach 1897-1924, II.194.7].

31 Froehner 1885, 56, No. 264 [=Reinach 1897-1924, II.194.3 = Köhne - Ewigleben 2000, 55. No. 49].

32 Katintcharov 1984, No. 214 [=Kunze 1990, 86, Abb. 38 = Reinach 1897-1924, III.156.10].

33 On mirror images and left-handed gladiators see BARTUs 2010, 35-40; WIRTH 2010.

34 Site: Brigetio/Szőny-Stadion út. Section: AJ-07-07. Stratigraphic unit: 1682. Package number: 0865/2019. Date of find: 26.08.2019. No inventory number yet. On the recent excavations in the legionary fortress of Brigetio see BARTus et al. 2018.

35 Dimensions: $85 \times 27 \times 12 \mathrm{~mm}$. Weight: $96 \mathrm{~g}$. Olive-green surface with red dots and patches. The left foot is missing.

36 The research on the present paper was supported by the Bolyai János Postdoctoral Scholarship, the National Research, Development and Innovation Office (NKFI 119520), and the Bolyai+ Postdoctoral Scholarship (ELTE Eötvös Loránd University). 

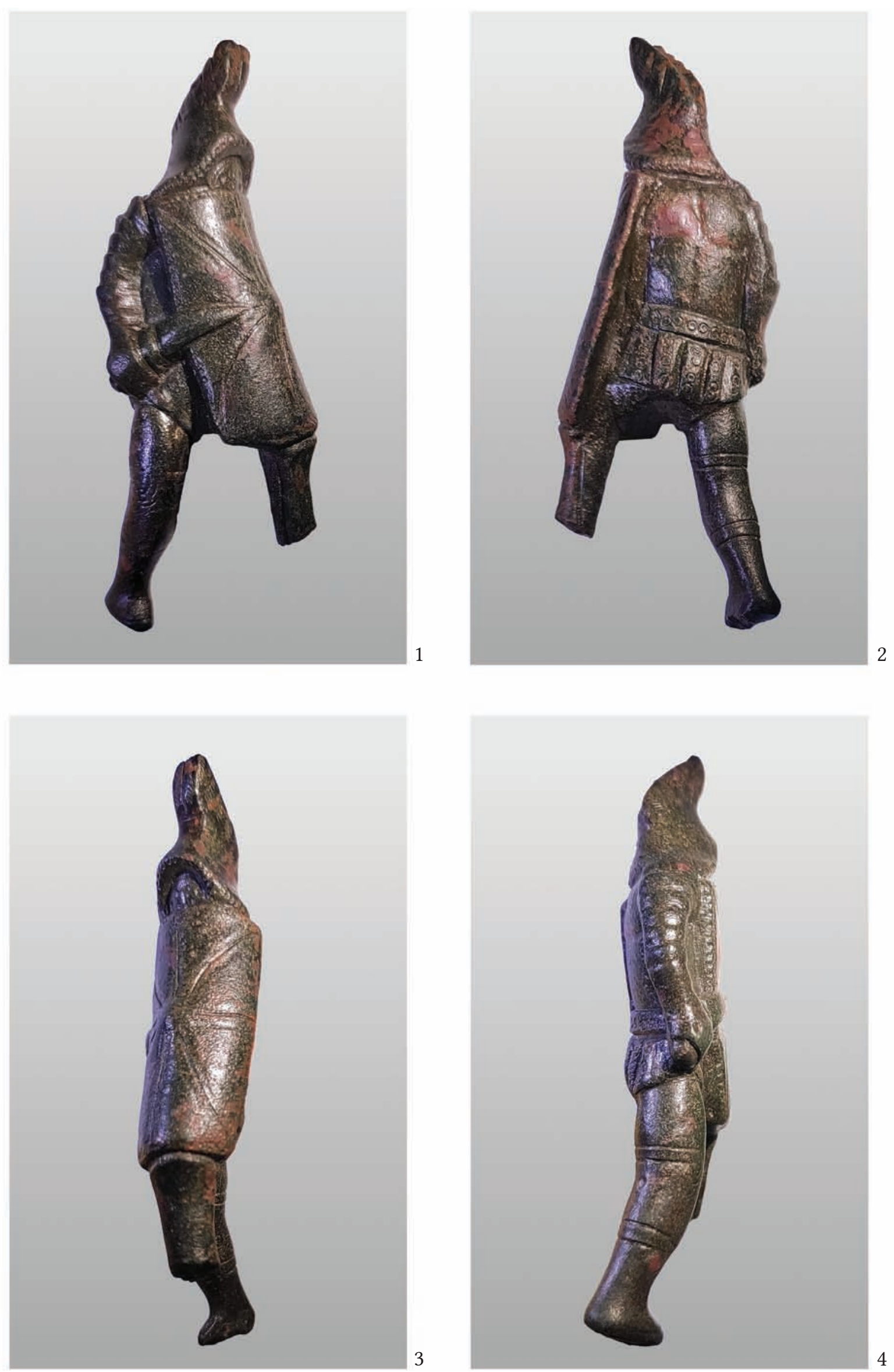

Fig. 1. 1-4 - The bronze gladiator from the legionary fortress of Brigetio. 
BARTus, D. 2010: Les manches de couteau à représentation de gladiateur de l'époque romaine. In: Borhy, L. (ed.): Studia celtica classica et romana Nicolae Szabó septuagesimo dedicata. Budapest, $27-50$.

Bartus, D. - Borhy, L. - Joháczi, Sz. - SzÁmadó, E. 2018: Short report on the excavations in the legionary fortress of Brigetio (2017-2018). Dissertationes Archaeologicae 3/6, 541-548.

Bartus, D. - Grimm, J. 2010: A knife handle from Caerwent (Venta Silurum) depicting gladiators. Britannia 41, 321-324.

Bayard, D. - Massy, J. L. 1983: Amiens romain. Amiens.

Le Bohec, Y. 2003: Inscriptions de la cité des Lingons. Inscriptions sur pierre. Paris.

Boucher, S. - Perdu, G. - Feugère, M. 1980: Bronzes antiques du Musée de la Civilisation GalloRomaine à Lyon. II. Instrumentum - Aegyptiaca. Lyon.

Bron, Ch. 1985: Les ivoires sculptés d'Avenches. Bulletin de l'Association pro Aventico 29, 27-48.

Degen, R. 1984: Eine römische Kleinplastik: Der Schafhirt von Cham-Hagendorn. Helvetia Archaeologica 15, 169-183.

DrČA, S. 1991: Sitna rimska bronzana plastika u narodnom muzeju u Nišu. Zbornik Narodni Muzej Niš 6-7, 19-42.

Durham, E. 2012: Depicting the gods: metal figurines in Roman Britain. Internet Archaeology 31, (http://intarch.ac.uk/journal/issue31/durham_index.html).

Eisenberg, J. M. 2004: Ancient Arms, Armor and Images of Warfare. Royal Athena Galleries. New York.

Eisenberg, J. M. 2014: Art of the Ancient World XXV. London-New York.

EspéRANDIEU, E. 1929: Inscriptions latines de Gaule (Narbonnaise). Paris.

Espérandieu, E. - Rolland, H. 1959: Bronzes antiques de la Seine-Maritime. Gallia Supplementum 13. Paris.

Facsády, A. - Zsidi, P. 2001: Romains de Hongrie. Ier-Ve siècles après f.-C. Musée de la Civilisation galloromaine, Lyon, décembre 2001 - mai 2002. Lyon.

Faider-Feytmans, G. 1979.: Les bonzes romains de Belgique. Mainz.

FAust, S. 2005: Figürliche Bronzen und Gegenstände aus anderen Metallen aus Stadt und Bezirk Trier in Privatbesitz III. Trierer Zeitschrift 67/68, 157-212.

Feugère, M. 2004: Découvertes récentes. Instrumentum 19, 34-35.

Fleischer, R. 1967: Die römischen Bronzen aus Österreich. Mainz.

Franken, N. 1994: Die antiken Bronzen im Römisch-germanischen Museum Köln. Die Bronzestatuetten ohne Fundortgabe. Die Statuetten aus dem Fund von La Comelle-sous-Beuvray. Kölner Fahrbuch 27, 405-511.

FrIEDRICHS, C. 1871: Berlins antike Bildwerke. II. Geräthe und Broncen im Alten Museum. Düsseldorf.

Froenner, W. 1885: Collection 7. Gréau. Catalogue des bronzes antiques et des objets d'art du Moyen Age et du Renaissance. Paris.

Garcia Serrano, R. 1990: Los bronces romanos en España. Madrid.

GotTschalk, R. 2006: Ein Gladiator im Kleinformat. Zu einem beinernen Klappmessergriff aus Carnuntum. Carnuntum Fahrbuch, 103-122.

Gschwantler, K. (ed.) 1986: Guß+Form. Bronzen aus der Antikensammlung. Wien.

HAMPEL, J. 1912: Kalauz a régiségtárban. Budapest.

Harris, J. 1994: A Passion for Antiquities. Ancient Art from the Collection of Barbara and Lawrence Fleischman. Malibu.

HómAn, B. 1928: Tíz év szerzeményei 1919-1928. A Magyar Nemzeti Múzeum kiállításai 5. Budapest.

Humer, F. - Kremer, G. (eds) 2011: Götterbilder - Menschenbilder. Religion und Kulte in Carnuntum. Ausstellung in Rahmen der Niederösterreichischen Landesausttellung 2011 „Erobern - Entdecken - 
Erleben im Römerland Carnuntum" im Archäologischen Museum Carnuntinum, Bad Deutsch-Altenburg 16. April 2011 bis 15. November 2012. Katalog des NÖ Landesmuseums NF 498. St. Pölten.

Junkelmann, M. 2000: Das Spiel mit dem Tod: So kämpfen Roms Gladiatoren. Mainz.

KatintchaRov, R. 1984: Le bronze sculpte de l'époque romaine au Musée archéologique national auprès de l'Académie bulgare des sciences. Sofia.

Kaufmann-Heinimann, A. 1977: Die römischen Bronzen der Schweiz. I. Augst. Mainz.

KIss, P. 2006: Urnák, hamvak, leletek. Régészeti feltárás Savaria északi temetőjében. Ókor V/2, 93-96.

KolEndo, J. 1998: Posążek z kości przedstawiający gladiatora (rękojeść składanego nożyka) z cmentarzyska w Grzybowie, Woj. Tarnobrzeskie. Swiatowit XLI, fasc. B, 414-439.

KöHne, E. - Ewigleben, C. (eds) 2000: Gladiators and Caesars: the power of spectacle in ancient Rome. London.

Kunze, M. 1990: Antike Bronzeplastik aus Bulgarien. Berlin.

LANDES, Ch. - CAZES, D. 1987: Les gladiateurs. Lattes.

Leibundgut, A. 1976.: Die römischen Bronzen der Schweiz. II. Avenches. Mainz.

Marazov, I. - Kabakchieva, G. - Lazov, G. - Shalganova, T. 2005: Vassil Bojkov Collection. Sofia.

MAYor, J. 1904: Aventicensia 3, Couteau àmanche d'ivoire sculpté représentant deux gladiateurs. Anzeiger für schweizerische Altertumskunde 5, 117-136.

MenZel, H. 1964: Römische Bronzen. Bildkataloge des Kestner-Museums, Hannover VI. Hannover.

Mercklin, E. 1940: Römische Klappmessergriffe. Serta Hoffileriana, Zagreb, 339-352.

Oggiano-Bitar, H. 1984: Bronzes figurés antiques des Bouches-du-Rhône. Gallia Supplementum 43. Paris.

Paulovics, I. 1942: Brigetioi kisbronzok magángyüjteményekből. Archaeologiai Értesittó 3, 216-245.

Piernavieja Rozitis, P. 1971-1972: Un gladiador ampuritano: Pardus. Ampurias 33-34, 381-384.

ProнÁszka, P. 2001: Römische Fibel mit Gladiatorendarstellung und Inschrift aus Pannonien. Communicationes Archaeologicae Hungariae, 65-86.

ReInAch, S. 1889: Antiquités nationales. Description raisonnée du Musée de Saint-Germain-en-Laye. Bronzes figurés de la Gaule romaine. Paris.

REINACH, S. 1897-1924: Répertoire de la statuaire grecque et romaine I-VI. Paris.

Speidel, M. P. 1994: Die Denkmäler der Kaiserreiter. Equites singulares Augusti. Köln.

SтоRсн, J. J. 1986: Senilus, el gladiador tracio (una navaja romana). Archivo Español de Arqueología 59, 219-226.

VELIČKović, M. 1972: Petits bronzes figurés romains au Musée national. Beograd.

Vermeule, C. - Сомstock, M. 1988: Sculpture in Stone and Bronze in the Museum of Fine Arts, Boston. Additions to the Collections of Greek, Etruscan, and Roman Art 1971-1988. Boston.

von SACKen, E. 1871: Die antiken Bronzen des k.k. Münz- und Antiken-Cabinetes in Wien. I. Die figuralischen Bildwerke classischer Kunst. Wien.

Vujović, M. 2011: Predstave gladijatora sa rimskih nalazišta u Srbiji. Zbornik Narodnog muzeja u Beogradu 20, 243-276.

Walters, W. B. 1899: Catalogue of the Bronzes in the British Museum. Greek, Roman \& Etruscan. London.

Wirth, H. 2010: Die linke Hand. Wahrnehmung und Bewertung in der griechischen und römischen Antike. Heidelberger Althistorische Beiträge und Epigraphische Studien 47. Stuttgart, 223-230. 
